\title{
THE EFFECT OF INTER FIRM KNOWLEDGE SHARING ON SUPPLY CHAIN AND FIRM PERFORMANCE: A CONCEPTUAL MODEL PROPOSAL
}

\author{
Huseyin INCE \\ Murat ÇEMBERCI \\ Gebze Institute of Technology, Turkey
}

\begin{abstract}
Inter-firm knowledge sharing (IKS) is identified as a significant predictor of positive performance in business relationships. On the premise that the effects of IKS have not been given the deserved scholarly attention in the SC supply chain context, this paper investigates the effects of IKS on sSupply cChain pPerformance (SCP) and fFirm pPerformance (FP). The hypothesized model is operationalised with survey data and analyzed using regression analysis. The findings add credence to the positive effects of IKS inter-firm knowledge sharing and identify IKS inter-firm knowledge sharing and supply chain performanceSCP as antecedents to higher FP firm performance in the SCsupply chain.
\end{abstract}

Keywords:: Inter-firm knowledge sharing, sSupply chain performance, fFirm performance.e

\section{Introduction}

As competition in the 1990s intensified and markets became global, so did the challenges associated with getting a product and service to the right place at the right time at the lowest cost. Organizations began to realize that it is not enough to improve efficiencies within an organization. Instead, , but their entirewhole supply chain (SC) hads to be made competitive. The Uunderstanding and practicing supply chain management (of SCM) has become an essential prerequisite for staying competitive in the global race and for enhancing profitably (Li \&and Lin, 2006).

Improving inter-organizational coordination and product quality, manufacturing firms often demand that their SC partners such as subcontractors or suppliers implement common processes, which often requires sharing process knowledge. Inter-organizational knowledge sharing within a SC has thus become a common practice, because it enhances the competitive advantage of the $\mathrm{SC}$ as a whole (Cheng et al., 2008).

Information sharing is a key ingredient for any SCM system. For example, mMany researchers have suggested that the key to athe seamless SC is making available undistorted and up-to-date marketing data available at every node within the SC. By taking the data available and sharing it with other parties within the SC, an organization can speed uacceleratep the flow of information flow in the SC, improve the chain's efficiency and effectiveness of the SC, and respond to customers' changing needs more quicklyer. ITherefore, information sharing, therefore, will bring the organization competitive advantages to the organization in the long run (Li \&and Lin, 2006).

The advantage of information sharing in SCM has been intensively discussed intensively. Information sharing improves coordination between SC processes to enable the material flow and reduces inventory costs. Information sharing leads to high levels of SC integration by enabling organizations to make dependable deliveriesy and introduce products to the market quickly. Quality information sharing also contributes positively to customer satisfaction and partnership quality. Thus, ilnformation sharing impacts the SCP in terms of both total cost and service level (Zhao et al., 2002).

Lin et al. (2002) suggested that athe higher level of information sharing is associated with the lower total costs, a the higher order fulfillment rate, and athe shorter order cycle time. While information sharing is important, the significance of its impact on the performance of a SC depends on what the type of information is shared, when and how it is shared, and with whom. The lLiterature is replete with examples of the dysfunctional effects of inaccurate/delayed information, particularly as information moves along the SC. Divergent interests and opportunistic behavior of SC partners, as well asnd 
informational asymmetries across the supply chain SC affect the quality of information (Feldmann \&and Mrller, 2003).

It has been suggested that organizations will deliberately distort information that can potentially reach not only their competitors, but also their own suppliers and customers. It appears, therefore, that there is a built-in reluctance within organizations become reluctant to give away more than the minimal information necessary because disclosing since information disclosure is perceived as a loss of power. and Ccompanies fear that information may leak to potential rivals. To facilitate quality information sharing across SCs, an understanding of the factors influencing information sharing is needed so that a strategy canmay be developed to overcome the barriers that preventing information sharing and encourage seamless information flow in SCs (Li \&and Lin, 2006).

Previous studies have addressed the importance of certain factors in information sharing and information quality in SCM supply chain management, but few studies have considered simultaneously the impact of intra-organizational factors, and inter-organizational factors on information sharing and in the context of SCM. To fill this gap, this studypaper first identifies a set of factors, including IKS (exchange of information, joint -sense- making, and knowledge integration), SCP (with customers, intra-functions and inter-organization), FP, and inter-organizational relationships (information sharing in SC partners) that may impact information sharing in SCM and FP. Then, it investigates the effects of IKS on SCM and FP.

The next section will reports a literature review of the literature that defines the variables under investigation. This is followed by the conceptual model and a discussion on the developingment of the research hypotheses. Following this, the methodology for the empirical part of the study and its implementation will be described before analyzing the results. Finally, this paper concludes withthere will be a discussion of the theoretical, research, and managerial implications of the study.

\section{LITERATURE REVIEW}

This study investigates the effects of IKS on SCP and FP. A review of related literature was undertaken with the primary focus ofon defining there research variables andas well as their the conceptualized relationships between them.

\section{Inter-firm Knowledge Sharing in Supply Chain}

Information sharing refers to the extent to which critical and proprietary information is communicated to one"s SC partners (Monczka et al., 1998). Many researchers have emphasized the importance of information sharing in SCM practice. Lalonde (1998), in fact, considereds sharing of information as one of five building blocks that characterize a solid SC relationship.

According to Stein and Sweat (1998), SC partners who exchange information regularly are able to work as a single entity. Together, they can understand the needs of the end customer better; and hence, they can respond to market changes more quicklyer. Moreover, Yu et al. (2001) pointed out that the negative impact of the bullwhip effect on a SC can be reduced or eliminated by sharing information with trading partners.

The empirical findings of Childhouse and Towill (2003) revealed that simplified material flow, including streamlining and making highly visible all information flowing throughout the chain, is the key to an integrated and effective SC.

Selnes and Sallis (2003) defineds IKS as "a joint activity between a supplier and a customer in which the two parties share information, which is then jointly interpreted into a shared relation-domainspecific memory that changes the range or likelihood of potential relation-domain-specific behavior" (p. xxx80). It is thus a process thato improves future behavior in a relationship. IKS is conceptualized as a joint activity in which the two firms strive to create more value together than they would create individually or with other partners. It is treated as a multi-dimensional construct with multiple facets, that includinge information sharing, joint sense- making, and integrating knowledge integration (Cheung, 2005).

\section{Exchange of Information}

Information sharing between the two parties in a customer-supplier relationship is a starting point and a necessary element of relationship learning. Research related to customer-supplier relationships has 
identified information sharing as a central element of working relationships. Anderson and Narus (1990) and Cannon and Perreault (1999) both discussed how two organizations must exchange information to coordinate and plan the working relationship, and thereby achievinge operational efficiency. Biong and Selnes (1996) related exchanginge of operative information to the tasks of a salesperson in ongoing relationships. In addition to the ongoing management of relationships, information sharing might also affect learning in the relationship. One of the respondents in the Cheung's (2005) field interviews commented,: "Mostly, we learn through communication. This is exactly the point we are trying to make with our customers. We want them to refer to us when they are developing new products or if they are making changes. We are trying to find contact points, regional and worldwide, who will work with us. This is something we are really working with, that is, to gain a mutual understanding with our customers for how we operate" "(Cheung 2005p. 80xxx).

\section{Joint -Sense- Making}

Dialogue within the relationship constitutes a relationship-specific element of interpretation or sense making (i.e., developing knowledge development) of the shared information. Fiol and Lyles (1985) linked interpretation closely with organizational learning when they defined learning as " "[t]he development of insight, knowledge, and associations between past actions, the effectiveness of those actions, and future actions" (p.. 80xxx).." Because organizations vary in the ways they make sense of the same information, there likely are differences in the mechanisms involved in making sense of that information are likely to emerge. It follows that some of the information acquired might be rejected, not because it is unimportant, but because the organization lacks the ability (i.e., the knowledge) to make sense of it. Organizations employ several mechanisms to make sense of information, Ffor example, they conduct board meetings, coordinate management meetings, and draw together task-force teams. Organizations also introduce specific arenas with the sole purpose to learn. F, for example, they implement information-sharing forums, as Huber (1996) suggesteds. Related to customersupplier relationships, cross-functional teams in customer visit programs have been suggested as a mechanism for creating learning arenas (Cheung, 2005).

In theour field interviews for this study, we wanted to learn how dialogues were organized in different customer-supplier relationships. The interviews revealed that most interactions between the two parties were related to solving some sort of operational problem. T and thus, such interactions were addressed in operational kinds of meetings or simply by telephone. There We did encounter,were, however, many examples of face-to-face meetings, such as customer visits and trade shows. The parties used these forums to build a more general understanding of each other and their respective operations.

\section{Knowledge Integration}

Organizations develop relationship-specific memories into which acquired relationship-specific knowledge is integrated. Walsh and Ungson (1991) argued that organizational memory is both an individual- and an organizational-level construct. Individuals retain information based on their direct experiences and observations, which are stored in their memories as cognition, beliefs, and values. At the organizational level, memory is decentralized and manifests itself in several places throughout the organization. This memory includes organizational beliefs, behavioral routines, and physical artifacts (Cheung, 2005).

\section{SUPPLY CHAIN PERFORMANCE}

The SC encompasses all activities associated with the flow of goods and information from sourcing of raw materials through to the end user (Handfield \&and Bechtel, 2002). The goals of manufacturers are critical in determining SC goals and therefore delineating SCP constructs. According to Handfield et al. (2000) and MacDuffie and Helper (1997), manufacturers wish to position themselves so they have more flexibility, lower costs, and and reduced lead time in their SC processes and lower costs. When the literature is researched, it is clearseen that the studies related to SCP measurement systems were significantbecame important. At the rYüksel (2004), for example,esearches, it is emphasized that because of the traditional performance criteria based on financial criteria isare historical, it can not determine the strategic performance criteria such as customer satisfaction and, product quality. And, because traditional performance criteria and do notn't consider the effects of uncertainty, they are deficient (Yüksel, 2004). 
The first stage for whichto companies must design SCP measurement systems is SC effectiveness, and they mustto find appropriate criteria to consider this effectiveness (Beamon, 1999). The criteria used to evaluateion SCP are different from traditional performance criteria as well asnd also the common conceptionpoint at all criteria is continuous development and end user satisfaction.

The literature suggests that four "competitive priorities" are critical in the measuringement of SCP, and includinge speed, quality, cost, and flexibility (Hult et al., 2007). Key parameters that have been conceptualised and empirically tested in the context of SCP (supplier--manufacturer relationships) include reducing costs reduction, reliable delivery, reliabilityimproving quality improvement, conformingance to specifications, minding lead times and, time to market, and improving processes improvement (Panayides \&and Lun, 2009).

\section{CONCEPTUAL MODEL AND RESEARCH HYPOTHESES}

\section{Conceptual Model Development}

The concept of SCM has come to re-ienforce the subject of logistics with a more comprehensive treatment that spans the entire value system from suppliers to customers (Handfield \&and Nichols, 2004). The Council of Logistics Management has defined SCM as " "encompassing the planning and management of all activities involved in sourcing and procurement, conversion and all logistics management activities. Importantly it also includes coordination and collaboration with channel partners, which can be suppliers, intermediaries, third party service providers, and customers" (cite and pg.

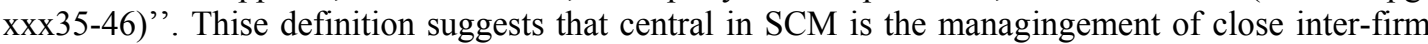
relationships, which are essential for achieving higher SCP. In fact, it has been specifically recognized specifically that to create a competitive advantage, SCM must is increasingly emphasizeing inter -organizational co-ordinations of activities (Panayides \&and Lun, 2009). Because Since interorganizational relationships are central in industrial SCs, and knowledge sharing is an important part of in the formingation of strong inter- organizational relationships, it is worthwhile to consider empirically potential organizational and performance consequences of knowledge sharing in SCs. This paper thusIt is conceptualizesd in this paper that knowledge sharing within a SC for its preferred supplier will have a positive impact on SCP that will also improve FP. In addition, uncertainty has a moderator effect between IKS and SCP. This study'se conceptual framework is depicted in Figure. 1.

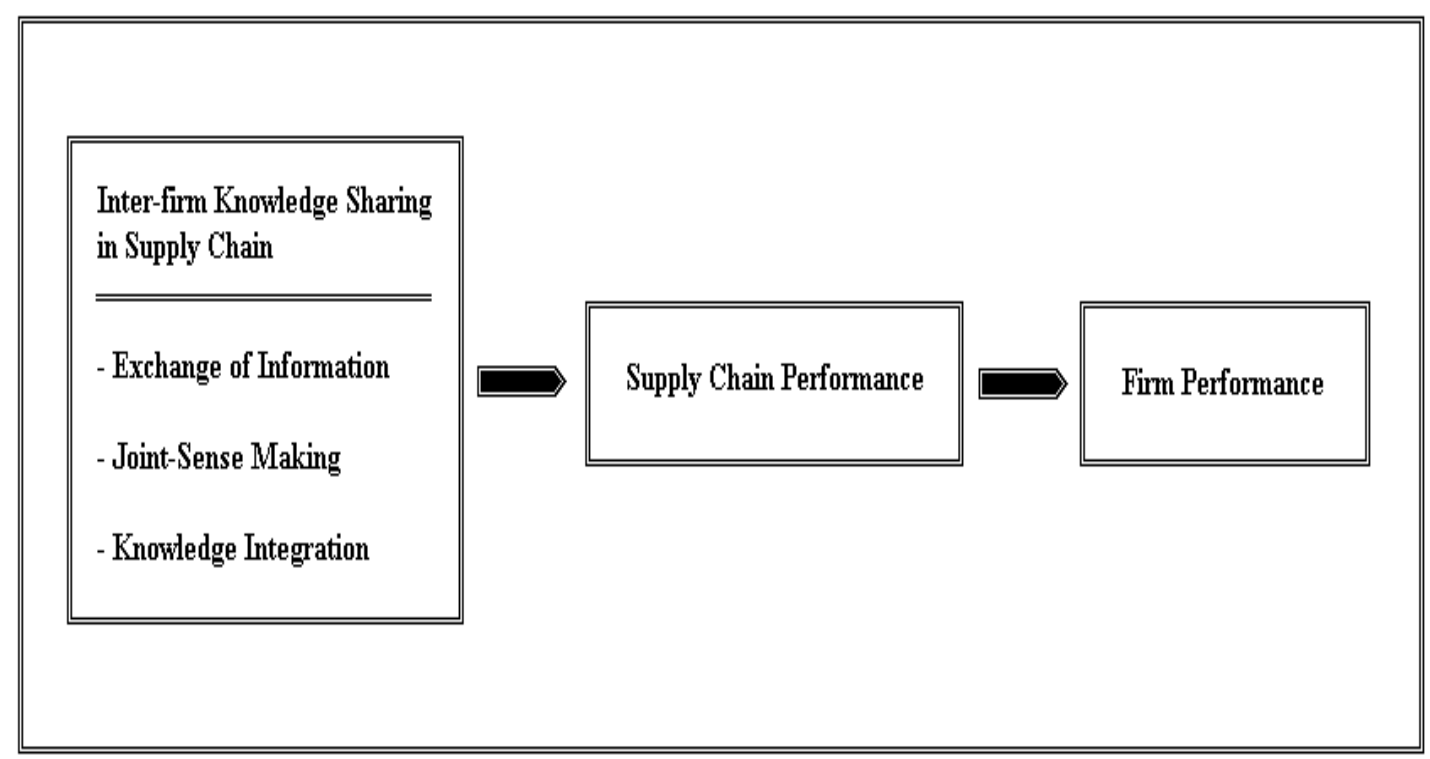

Fig. 1. Conceptual Framework of This Study 


\section{RESEARCH HYPOTHESES}

This section aims toat developing theoretically justified hypotheses of how IKS in SCM may influence SCP and FP, and also how uncertainty plays a moderator role between IKS in SCM and FP.

\section{The Effect of Inter-firm Knowledge Sharing in the Supply Chain on Supply Chain Performance}

Fawcett et al. (2007) emphasized that firms' the knowledge sharing capabilities of firms are the determineant of SCP. ILi and Lin (2006), in their model, Li and Lin (2006) also imported that knowledge sharing determines SCP. Zhou and Benton (2007), highlighted that knowledge sharing determines the performance of how the SC isthe implementedation of SC. Crook et al. (2008) researched the effect of knowledge sharing on SCP and represented that the role of knowledge sharing on the effectiveness of SC is also very important. Petersen (1999), investigating the effect of the quality of information on the performance of an SC knowledge sharing model has identified as an indicator of the supply chain's performance of SC. MThere are many other studies in the literature that supports thate knowledge sharing indicates the supply chain's performanceis an indicator of SCP. Thus, we hypothesize:

H1. Exchange of information is positively related to supply chain performance.

H2. Joint -sense- making is positively related to supply chain performance.

H3. Knowledge integration is positively related to supply chain performance.

\section{The Effect of Supply Chain Performance on Firm Perform- ance}

Effective SCM has become a potentially valuable way toof improveing organizational performance and storeing competitive advantage in the SC. Li et al (2009) Iin their model, Li et al. (2009) structured the five dimensions of SCM practices and, concluded that athe high level of SCM practice increased competitive advantage and FP.

Koh et al. (2007) surveyed the effect of SCM practices on FP and stated that SCM practices have a significant and positive effect on the FP. Further, Bayraktar et al. (2009) in their research stated that SC practices are positively related with FP and that SC practices have an effect on FP. Indeed, mThere are many studies in the literature that supports the knowledge sharing is an indicator of SCP. Thus, we hypothesize:

H4. Supply chain performance is positively related to firm performance.

\section{RESEARCH METHOD}

\section{Sample and Data Collection}

Using a multiple-choice scale, the hypotheseis given above are tested. Answers were measured using a 5 -point $(1=$ strongly agree, $5=$ definitely disagree) $1-5$ Likert-type scale, with between 1 and $51=$ strongly agree and $5=$ definitely disagree). In the study survey, scales took place of the questions that have beenare used previouslybefore in the developed Wwestern countries. The questions in this study's scale were adopted from foreign publications and translated into Turkish. Then, the questions translated into Turkish were compared with the original by a different expert who back translated the questionsturning into English. At the end of this comparison, surveys were distributed to the appropriate people after confirmingation with the original and translated questionsion.

According to 2010 data provided by thefrom Istanbul Chamber of Commerce, we have accessed to a sample exist of 250 firms within the first 500 largest 500 firms. Surveys are sent to all firms in our sample. Top- and middle- level managers were asked to fill in the surveys to representing the company. Tools were used such as e-mail and face-to-face interviews were used to collect in data collection. As a result, the return of 237 pieces surveys provided from 175 companies were returned. In this sense, the percentage of returnresponse rate for the surveys wais $70 \%$ on a firms basis. Obtained surveys were evaluated statistically. The data set was evaluated using ain the data processing program. TIn order to test the relationships between variables.; factorFactor, reliability, correlation, and regression analysis were completed done. 


\section{Scale Development}

IKS is defined as an ongoing joint activity between the customer and the supplier organizations directed at sharing information, making sense of information, and integrating acquired information into a shared relationship-domain-specific memory to improve the range or likelihood of potential relationship-domain--specific behavior. Previous studies by Anderson and Narus (1990), Heide and John (1992), Moorman and Miner (1997), Noordewier, John, and Nevin (1990), and Slater and Narver (1996) provided guidance in developing the items (Selnes \&and Sallis, 2003).

This scale was borrowed directly from Selnes and Sallis (2003). It is a second order construct with three dimensions: exchange of information, joint -sense- making and knowledge integration. Selnes and Sallies (2003) developed the 17- item scale through a set of qualitative interviews with managers in a context similar to this dissertation.

The SCP scale was adopted as key parameters that have been conceptualised and empirically tested in the context of SCP (sSupplier--manufacturer relationships). The scale, adopted from Cheung (2005) It is included questions about reducing costs reduction, reliable delivery reliability, improving quality improvement, conformingance to specifications from, minding lead times and, time to market, and improving processes improvement, adopted from Cheung (2005).

To measure FP, we asked 16sixteen questions were asked. These were adopted from Ellinger et al. (2002) and Akgün et al. (2007). BecauseSince a multi-company and multi-industry sample was used (i.e., selectingon of a diverse set of industries improves the generalizability of the research findings to a broader population), performance differences in the nature of firms were controlled by using relative performance measures. FP was assessed relative to the achieving ement of organizational goals related to profitability and growth in sales and market share.

\section{EMPIRICAL ANALYSIS AND RESULTS Descriptive Statistics and Measurement Model}

The correlation matrix and descriptive statistics indicate the variables' means to be below 5 . The standard deviations for the variables range from 0.40 to 0.72 indicating a considerable amount of variation in the responses. The correlations provide an initial test of the research hypotheses. The four hypotheses are supported at the $p<0.01$ level. The values of the correlations range from 0.187 to 0.467 , with the mean being 0.35 (see Ttable 2).

An effective measurement instrument should cover the content of the domain of each construct. Content validity is one of the basic requirements for a good measure. Content validity indicates that an instrument's the measurement items in an instrument cover the major content of a construct. EThe evaluatingon of content validity is a rational judgmental process not open to numerical evaluation (Panayides \&and Lun, 2009). To achieve content validity, it is essential to undertake a comprehensive literature review, which facilitated the choice of well-established measurement scales thatwhich were adopted and validated measurement items. According to the results of the factor analysis shown Ttable 1, structural validity of the concepts is provided. $b$ Because, the factor loadings wereare greater than $0.50,0.50$ and each variables is loaded only a single factor.

Reliability values indicate the degree to which operational measures are free from random error and measure the construct in a consistent manner (Panayides \&and Lun, 2009). Reliability is typically assessed using Cronbach's alpha values. A scale is found to be reliable if the coefficient is 0.70 or higher for confirmatory factor analysis (Panayides \&and Lun, 2009). The reliabilities of the scales are shown in Ttable 1. All values exceed the recommended cut- off point of 0.70 . 
Journal of Global Strategic Management | V. 5 | N. 1 | 2011-June | isma.info | 50-61 | DOI:10.20460/JGSM.2011515812

Table 1. Standardized Measurement Coefficients

\begin{tabular}{|c|c|c|c|c|c|}
\hline & $\begin{array}{l}\text { Exchange of } \\
\text { Information }\end{array}$ & $\begin{array}{l}\text { Joint sense- } \\
\text { making }\end{array}$ & $\begin{array}{l}\text { Knowledge } \\
\text { Integration }\end{array}$ & $\begin{array}{l}\text { SC Perform- } \\
\text { ance }\end{array}$ & $\begin{array}{l}\text { Firm Perform- } \\
\text { ance }\end{array}$ \\
\hline ei5 & .806 & & & & \\
\hline ei4 & .738 & & & & \\
\hline ei2 & .704 & & & & \\
\hline eil & .620 & & & & \\
\hline jsm7 & & .804 & & & \\
\hline jsm6 & & .721 & & & \\
\hline jsm8 & & .514 & & & \\
\hline ki17 & & & & & \\
\hline ki13 & & & .802 & & \\
\hline ki12 & & & .804 & & \\
\hline ki14 & & & .856 & & \\
\hline scp6 & & & & .845 & \\
\hline scp8 & & & & .797 & \\
\hline scp7 & & & & .772 & \\
\hline scp3 & & & & .746 & \\
\hline scp4 & & & & .710 & \\
\hline scp5 & & & & .616 & \\
\hline fp7 & & & & & .900 \\
\hline fp12 & & & & & .899 \\
\hline fp6 & & & & & .854 \\
\hline fp13 & & & & & .852 \\
\hline fp5 & & & & & .834 \\
\hline fp16 & & & & & .800 \\
\hline fp8 & & & & & .725 \\
\hline $\mathrm{fp} 2$ & & & & & .535 \\
\hline $\begin{array}{l}\text { Cronbach's } \\
\text { alpha }\end{array}$ & 0.77 & 0.71 & 0.79 & 0.88 & 0.95 \\
\hline
\end{tabular}

$\mathrm{N} \mathrm{n}=237$; , Total explained variance is $\% 73.85 \%$ 
Table 2. Means, Standard Deviations, and Correlation Matrix

\begin{tabular}{|c|c|c|c|c|c|c|c|}
\hline Variable & Mean & $\begin{array}{l}\text { Std. Devia- } \\
\text { tion }\end{array}$ & $\begin{array}{l}\text { Exchange of } \\
\text { Information }\end{array}$ & $\begin{array}{l}\text { Joint } \\
\text { sense- } \\
\text { making } \\
\end{array}$ & $\begin{array}{l}\text { Knowledge } \\
\text { Integration }\end{array}$ & $\begin{array}{l}\text { Supply Chain } \\
\text { Performance }\end{array}$ & $\begin{array}{l}\text { Firm Per- } \\
\text { formance }\end{array}$ \\
\hline $\begin{array}{l}\text { Exchange of } \\
\text { Information } \\
\text { Joint-sense }\end{array}$ & 4,08 & 0,44 & 1 & & & & \\
\hline $\begin{array}{l}\text { Making } \\
\text { Knowledge }\end{array}$ & 3,46 & 0,72 & $0.187^{* *}$ & 1 & & & \\
\hline $\begin{array}{l}\text { Integration } \\
\text { Supply Chain }\end{array}$ & 3,96 & 0,51 & $0.345^{\star *}$ & $0.467^{* *}$ & 1 & & \\
\hline $\begin{array}{l}\text { Performance } \\
\text { Firm Perform- }\end{array}$ & 3,90 & 0,40 & $0.246^{* *}$ & $0.415^{\star *}$ & $0.307^{* *}$ & 1 & \\
\hline ance & 3,74 & 0,55 & -0.098 & $0.364^{* *}$ & 0.086 & $0.430^{* *}$ & 1 \\
\hline
\end{tabular}

** Significant at $p<0.01$

\section{Regression Analysis}

To test the factors impacting SCP, we conducted linear regression analysis is conducted, using the three influencing factors as independent variables and SCP as the dependent variable. AndIn addition, also to test impacting FP, linear regression analysis wasis conducted, using one influencing factor as an independent variable and FP as the dependent variable. The results are shown in Ttable 3 and Ttable 4.

The first regression model shown in Ttable 3 is significant $(\mathrm{F}=20,424$, sig $<0,01)$ and explained \% $20 \%$ of the observed variation in the independent variable. As stated H1., H2., and H3, exchange of information, joint -sense- making, and knowledge integration haves a positive and significant effect on SCP. In other words, the first regression model supports H1., H2., and H3.. As are supported by the first regression model. It can be seen also in Ttable 3, SCP is influenced positively by joint -sensemaking, exchange of information, and knowledge integration in SC partners. The higher the level of joint -sense- making, exchange of information, and knowledge integration in SC partners, the higher the level of SCP. The results shown in Ttable 3 thus indicate the importance of inter-organizational relationships in SCP.

\section{Table 3. The Regression Analysis of Supply Chain Performance}

\begin{tabular}{|lll|}
\hline Independent Variables & $\hat{\mathrm{a}}$ & Sig. \\
\hline Join -sense-m Making & 0,343 & 0,000 \\
Exchange of Information & 0,150 & 0,017 \\
Knowledge Integration & 0,095 & 0,170 \\
\hline Dependent Variable is Supply Chain Performance & & \\
R2=0.198 F=20.424 & & \\
\hline
\end{tabular}

Significant at $p<0.01$

The results show in Ttable 4, the second regression model, are alsois significant $(\mathrm{F}=53,388$, sig $<0,01)$ and explained $\% 19 \%$ of the observed variation in the independentd variable. As stated H4., SCP has a positive and significant effect on FP. In other words, the second regression model supports H4. is supported by the second regression model. AsIt can be seen also in T table 4, FP is influenced positively by SCP. The findings add credence to the positive effects of IKS and identify IKS and SCP as antecedents to higher FP in the SC. 
Table 4. The Regression Analysis of Firm Performance

\begin{tabular}{|l|l|l|}
\hline & $\hat{\mathrm{A}}$ & Sig. \\
\hline Independent Variables & & \\
Supply Chain Performance & 0,430 & 0,000 \\
\hline $\begin{array}{l}\text { Dependent Variable is Firm Performance } \\
\mathrm{R} 2=0.185 \quad \mathrm{~F}=53.388\end{array}$ & & \\
\hline Independent Variables & & \multicolumn{1}{|c|}{ Sig. } \\
\hline Supply Chain Performance & 0,000 \\
\hline $\begin{array}{l}\text { Dependent Variable is Firm Performance } \mathrm{a}=53.388 \\
\mathrm{R}^{2}=0.185 \text { 0,430 }\end{array}$ \\
\hline
\end{tabular}

Significant at $p<0.01$

\section{DISCUSSION AND IMPLICATIONS}

\section{Theoretical Contributions}

The literature has indicated that relationships between firms are an important unit of analysis for explaining firms' profit returns; that is, firm , i.e., performance (Panayides \&and Lun, 2009). This paper investigates empirically this relationship in the supply chainSC context by specifically focusing on one of the most significant parameters of inter-firm knowledge sharingin IKS and assessing its impact on SCP and FP. The empirical findings generally support the proposed model of the consequences of IKS in terms of contributing to SCP and FP. The findings add credence to the relational paradigm, which suggests the beneficial performance outcomes of IKS in particular. The findings also suggest that IKS as a whole will facilitate a better understanding the SCP, which that will reflect needs for service and processes in the SC more accurately. It must be emphasized that IKS contributes not only to SCP, but also importantly to improving firm performanceement of the FP. The findings support the notion that cooperation has a significant and positive effect on SCP (Morris \&and Carter, 2005). Exchange of information appears to be one of thea key success factors in improving SCP, providing support for the study's H1. This finding supports previous work on the nature of information sharing in business relationships. High levels of information sharing enable the partners to focus on the longterm benefits of the relationship and ultimately SCP.

The results from testing the second research hypothesis $(\mathrm{H} 2)$ indicate the value of joint -sense- making in terms of improving SCP. Hence, developingment of knowledge sharing in supply chain relationshipsSCs will lead to beneficial performance out comes as identified in this study. The positive impact of knowledge sharing on SCP was also identified by Zhou and Benton (2007), who highlighted that knowledge sharing determines the performance of the implementing theation of SC. Similarly, Crook et al. (2007) researched the effect of knowledge sharing on SCP and represent that the role of knowledge sharing on the effectiveness of SC is very important. Hence, the hypothesized relationship and the empirical findings in this study provide support to the theoretical notion of a positive association between knowledge integration and SCP in the SCsupply chain performance. The results from testing the third research hypothesis (H3) indicate the value of integrating knowledge integration in terms of improving supply chain performanceSCP. SCP is an essential factor for overall firm performance FP, providing support for hypothesis 4 (H4). In their model, Li et al. (2006), in their model structured the five dimensions of SC management practices and, concluded that athe high level of SC management practice increased competitive advantage and FP.

These are found to be critical issues in improving SCP. The results come to support previous empirical findings in the literature that innovation capability is among the most important determinants of FP. THowever, this study breaks new ground, however, by empirically supporting a link between IKS and SCP and FP.

\section{Managerial Implications}

The findings suggest that managerial, organizational, and inter-organizational capabilities can have an effect supply chain performance on SCP. Manufacturers and their suppliers are should become well 
informed of the potentially beneficial effects of IKS and SCP. By promoting information sharing and facilitating organizational relationships, managers can enhance positional advantage bythrough achieving better performance in their SC operations (Panayides \&and Lun, 2009). This study has found that IKS will positively influence SCP and indirectly FP. It is therefore important for managers to understand the key parameters that give riseenhance to knowledge sharing with suppliers and monitor how those factors can betheir improvedment. Manufacturers may invest resources in the enhancingement of exchange of information with suppliers to promote the developingment of IKS. The partners should work together to identify areas for improvement areas and share information that will facilitate timely and efficient supply chainSC operations. As this study found by this study, IKS can positively influence SCP and FP. Manufacturers may be confident of high returns for promoting and encouraging knowledge sharing between their partners. This can be achieved by firstly showing commitment to sharing information from the top, encouraging managers and line employees to development and implementation of new ideas and processes, and rewardinging creativity that can occur anywhere in the organization.

\section{Limitations and Further Research}

As with most empirical and survey-based research, the present study experienced several re are a few limitations experienced during the present study. First, tThe sample was restricted to Turkish manufacturers. Whereas and while this serves to control for extraneous sources of variation, caution should be used in extrapolating the results to other contexts.

Future research must address the issue of other consequences of IKS in general ands well as antecedents to SCP as well asand consider the impact on the economic performance of the firms (manufacturer-supplier) in addition to SCP, which that was examined in this case. Bearing in mind the strategic and practical importance of high performing SCs and the current level of empirical understanding, this is a prominent area for further research. 


\section{REFERENCES}

Akgün A. E., Keskin H., Byrne J. C., Aren S., (2007), Emotional and learning capability and their impact on product innovativeness and firm performance, Technovation 27, pg. 501-513.

Bayraktar E., Demirbag M., Koh S.C.L., Tatoglu E., Zaim H., (2009), A causal analysis of the impact of information systems and supply chain management practices on operational performance: Evidence from manufacturing SMEs in Turkey, Int. J. Production Economics, pg. 1-17.

Beamon B.M., (1999), Measuring Supply Chain Performance, International Journal of Operations \& Production Management, Vol: 19, No: 3, pg. 295-310.

Cheng J., Yeh C., Tu C., (2008), Trust and knowledge sharing in green supply chains, Supply Chain Management: An International Journal 13/4,pg. 283-295.

Cheung M., (2005). Inter-firm knowledge sharing and its effect on relationship value: A global supply chain perspective, A dissertation Presented for the Doctor of Philosophy Degree, The University of Tennessee, Knoxville, pg. 25-28.

Childhouse P, Towill D.R., (2003), Simplified material flow holds the key to supply chain integration. Omega-Int. J. Manage. S. 31(1): pg. 17-27.

Crook T. R., Giunipero L., Reus H.T., Handfield R., William K.S., (2008), Antecedents and Outcomes of Supply Chain Effectiveness: An Exploratory Investigation, Journal of Managerial Issues; 20, 2; ABI/INFORM Global, pg. 161.

Ellinger A.D., Ellinger A.E., Yang B., Howton S.W., (2002), The relationship between the learning organization concept and firm's financial performance: an empirical assessment. Human Resource Development Quarterly 13 (1), pg. 5-21.

Fawcett S. E., Osterhaus P., Magnan M.G., Brau J. C., Mccarter M. W., (2007), Information sharing and supply chain performance: the role of connectivity and willingness, Supply Chain Management: An International Journal 12/5, pg. 358-368.

Feldmann M., \& Mrller S., (2003), An incentive scheme for true information providing in supply chains. OMEGA, pg. 63-73.

Handfield R. B., Krause D. R., Scannell, T. V., Monczka, R. M., (2000), Avoid the Pitfalls in Supplier Development. Sloan Management Review, 41: pg. 37-49.

Handfield R.B., Bechtel C., (2002), The role of trust and relationship structure in improving supply chain responsiveness, Industrial Marketing Management 31, pg. 367-382.

Handfield R.B., Nichols E.L., (2004), Key issues in global supply base management. Industrial Marketing Management 33, pg. 29-35.

Hult G.T.M., Ketchen D.J., Arrfelt M., (2007), Strategic Supply Chain Management: Improving Performance Through A Culture of Competitiveness and Knowledge Development, Strategic Management Journal Strat. Mgmt. J., 28: pg. 1035-1052.

Koh S. C. L., Demirbag M., Byraktar E., Tatoglu E., and Zaim S., (2007), The impact of supply chain management practices on performance of SMEs, Industrial Management \& Data Systems, 107(1), pg. 103-124.

La Londe B.J., (1998), Supply chain evolution by the numbers. Supply Chain Management Review, Vol.02, Iss.1; pg. 7-8.

Li G., Yang H., Sun L., Sohal A.S., (2009), The impact of IT implementation on supply chain integration and performance, Int. J. Production Economics 120, pg. 125-138.

Li S., Lin B., (2006), Accessing information sharing and information quality in supply chain management, Decision Support Systems 42, pg. 1641-1656.

Lin F., Huang S., and Lin S., (2002), Effects of information sharing on supply chain performance in electronic commerce, IEEE Transactions on Engineering Management, 49(3): pg. 258.

MacDuffie, J.P. and Helper S., (1997), Creating Lean Suppliers: Diffusing Lean Production Through the Supply Chain, California Management Review, Vol. 39, No. 4, pg. 118-151. 
Monczka R.M., Petersen K.J., Handfield R.B., Ragatz G.L., (1998), Success factors in strategic supplier alliances: The buying company perspective, Decision Science, 29, 3; ABI/INFORM Global, pg. 553-578.

Morris M., Carter C.R., (2005), Relationship marketing and supplier logistics performance: an extension of the key mediating variables model, The Journal of Supply Chain Management 41, pg. 3243.

Panayides P.M., Venus Lun Y.H., (2009), The impact of trust on innovativeness and supply chain performance, Int. J. Production Economics 122, pg. 35-46.

Petersen K. J., (1999), The effect of information quality on supply chain performance: An interorganizational information system perspective, A dissertation submitted to Michigan State University in partial fulfillment of the requirements for degree of Doctor of Philosophy, pg. 34-46.

Selnes F., Sallis J., (2003), Promoting Relationship Learning, Journal of Marketing, 67, pg. 80-95.

Stein T. and Sweat J., (1998), Killer supply chains, Informationweek, Vol. 708 No.9, pg. 36-46.

Yüksel H., (2004), Tedarik Zincirleri için Performans Ölçüm Sistemlerinin Tasarımı, Celal Bayar Üniversitesi, İ.İ.B.F., Yönetim ve Ekonomi Dergisi, Cilt: 11, Sayı: 1, pg. 148-153.

Zhao X., Xie J., Zhang W.J., (2002), The impact of information sharing and ordering co ordination on supply chain performance, Supply Chain Management; 2002; 7, 1, ABI INFORM Global, pg. 24-40.

Zhou H., Benton W.C., (2007), Supply chain practice and information sharing, Journal of Operations Management 25, pg. 1348-1365. 